\title{
Competitiveness of Arabian Gulf Ports from Shipping Lines' Perspectives: Case of Sohar Port in Oman
}

\author{
Adil Khalid ${ }^{1}$ iD, Mohamed Al-Mamery² iD \\ ${ }^{1}$ Sohar University (Oman) \\ ${ }^{2}$ Sohar Port and Free Zone Company (Oman) \\ a.hassan@sobaruni.edu.om,reemruba@omantel.net.om
}

Received: July 2019

Accepted: October 2019

\begin{abstract}
:
Purpose: The purpose of this article is to study the factors that encourage shipping lines to use port of Sohar, in Oman. Some selected factors were used to assess to what extent it affects the port choice from shipping lines companies' perspective. These factors include infrastructure, hinterland, connectivity and port's dues.
\end{abstract}

Design/methodology/approach: For this study both quantitative and qualitative research methods were used. Self-administered questionnaire used for collecting quantitative data while interviews were used to collect qualitative data. Secondary data was collected by reviewing academic literature and recent relevant articles and reports.

Findings: Port of Sohar has a better opportunity to be the gateway of the Gulf Cooperation Council (GCC) States and all Cargo could have dropped in the port and transferred to other GCC States by road, rail and other transportation modes. This opportunity is gained by the strategic location of Sohar Port outside of the Strait of Hormuz. It can be concluded that port competitiveness can be improved through strategic location, improved hinterland conditions, port facilities, services cost, volume of cargo, connectivity to other ports and dwell time factor.

Research limitations/implications: The research was limited mainly by conducting it only at the port of Sohar because surrounding ports are too far away and it should involve more ports to gain comparative results. Limited number of stakeholders as Port Authority, Oman International Container Terminal (OICT) and shipping lines companies and agents is another limitation.

Practical implications: The port can improve its competitive advantages and focus on the investigated factors. The government can also continue in working in the three big infrastructural projects; the new express roads, Sohar Airport and rail network connections with other GCC networks.

Originality/value: The study used specific factors that expected to contribute to the shipping lines companies' selection of ports in the gulf region. This could help the port to identify their competitive advantage and how they can use these competencies to improve their competitiveness in relation to other ports in the region.

Keywords: Sohar Port, infrastructure, hinterland, connectivity, dues, competitiveness

\section{To cite this article:}

Khalid, A., \& Al-Mamery, M. (2019). Competitiveness of Arabian Gulf Ports from shipping lines’ perspectives: Case of Sohar Port in Oman. Journal of Industrial Engineering and Management, 12(3), 458-471. https://doi.org/10.3926/jiem.2982 


\section{Introduction}

There are some leading ports in the Arabian Gulf region. Port of Jabal Ali is one of these leading Ports, located in Dubai in the United Arab Emirates (UAE). It has been competing with other ports in the region. The relatively new and small port is Sohar Industrial Port, in Oman. Sohar Port is one of the recently developed ports in the Sultanate of Oman. It is located just before the Strait of Hormuz within easy reach and access. Specially for the booming economy of the Arabian Gulf States and the Indian subcontinent. This location provides great connectivity to Abu Dhabi, Dubai in the United Arab Emirates, Muscat the capital of Oman and other Gulf main cities as Riyadh, in KSA.

Sohar Port is run by Sohar Industrial Port Company (SIPC). It aims at establish an excellent industrial port in Sohar by creating an attractive investment package for maritime and industrial activity. SIPC is a joint venture between the Port of Rotterdam in the Netherlands and the Government of Oman (Lammers, 2013). SIPC is part of Sohar Industrial Port Group (SIP Group), which includes Sohar Industrial Port Company (SIPC), Sohar International Development Company (SIDC), Sohar Free Zone (SFZ), Sohar Port Special Projects Company (SPSP), Sohar Bulk Terminals Company (SBTC) and Sohar Port Pilotage Company (SPPC). Sohar industrial Port and Free zone offers a range of benefits for companies to invest in the free zone. In 2002, a major concession agreement was signed between the government of Oman and Sohar port and Free zone company SAOC (SIPC) which gives Sohar Port and Free zone the ability to manage and developing a new industrial zone on an approximately 4.5 hectare.

Competition between regional ports is rising as global container trade and ship sizes increased. This situation leads to an increasing bargaining power of shipping lines. These new circumstances create challenges for ports to adapt to cater big ship size, long ship draught, and dynamics supply chains. Moreover; shipping lines and agents have different interests that create difficulties for ports to achieve high levels of satisfaction for all parties. To facilitate trade it should provide efficient transportation systems which links the entire system (Steven \& Corsi, 2012). To benefit from economies of scale, vessels become bigger every year after year. The average vessel capacity is 18000 TEUs (Twenty-foot equivalent unit) with port to call at terminal operators and shipping line have opportunities for growing their business due to a rise in the volume of cargo transported around the world and dynamic supply chain connection (Steven \& Corsi, 2012).

This paper contains six sections. Section one presents the problem and background. The conceptual framework is developed in section two. In the third section, the paper main aim, objectives, questions and hypotheses are presented. The paper methodology is shown in section four while section five presents the results. Finally, section six includes conclusion and implications for future research.

\section{Problem and Background}

The port of Sohar currently handles compensation of break-bulk cargo, roll on roll off (RORO) vehicles, containers and liquid bulk and operates under landlord model structure. Different types of cargo have been identified as relevant to Sohar Port based on activity at the port which are currently moving through competing facilities in the Middle East region. It competes with Jabil Ali in Dubai, the flagship port of DPW (Dubai Port World), handling millions TEU per year. Sohar Port and Free Zone facility is located on Oman's northern coast. Is already acting on the economic diversification by competing for the traffic with other ports the in Gulf. According to the Commercial Manager for Sohar port, Edwin Lammers; “... as part of Oman's goal to diversify its economic the port plan to handle cargo for the entire Gulf region ...".

Recently; Sohar port completed $\$ 13$ million expansions of its new containers terminal and plans for further expansion as it aims to increase its containers capacity to four millions TEUs (Twenty-foot equivalent unit) in near future. The port authority believes it will be in the position to be extremely competitive with other ports in the region especially Port of Jabil Ali (Pacific Tycoon, 2014).

Ports competitive advantage affected by different factors including the growing usage of door-to-door logistic and supply chain as they are considered to be inland costs (Notteboom \& Rodrigue, 2005). The inland transport must be improved and developed because of its importance to the competitive situation of terminal operating 
companies in supply chain. Furthermore; the terminal operation can be improved by the terminal operating companies who have the ability to develop the facilities and increase the volume and capacity of terminals, which will remove the difficulties in inland transport and transportation issues (Chen et al., 2006). There should be a balance between shipping line companies and hinterland transport companies in order to cooperate among them (De Langen \& Chouly, 2004). It is clear that there are a limited number of shipping companies which dominate the shipping business in Sohar, but conversely there are a lot of companies that provide hinterland.

Door-to-door transport serve is an important role to companies and organizations (Gunasekaran \& Sarkis, 2008). It can improve organizational competitiveness toward the enhancement of materials and information flows along logistics and the supply chain. Previous studies were focused on logistics to traditional brick and mortar firms, few of these studies were focusing on the importance of door-to-door transport (Ramanathan, 2010). Different type of service is an essential part of port competition (Ellram, Tate \& Feitzinger, 2013).

Some authors argued that supply chain, freight forwarding, technological, human and logistical aspects of service quality can effect customer satisfaction and firm competitiveness (Jie, Subramanian, Ning \& Edwards, 2015). Especially with the growth of customer attention to the services provided by companies, quality of service and supply chain and logistics services have become more and more essential. Studies in operation management have called for more focus on selection and contract management of door-to-door transport service for building collaborative logistics and supply chain partnerships (Sahay, Gupta \& Mohan, 2006). According to Ramanathan (2010), later arrival or non-arrival of the services, products, accuracy of the order and damage of the product significantly increases customer dissatisfaction.

The consumer selection aspects of such companies are the availability of door-to-door facilities, which are based on service infrastructure, information technology and flexibility of the service to get customer satisfaction by goods delivery from and to the consumer (Coltman \& Devinney, 2013). Most competition factors can be inherited like generated infrastructure or natural recourses, facilities, effectiveness and efficiency (Jie et al., 2015). As an important competitive process, the agile logistics and supply chain strategy is targeting to achieve flexibility and adaptability in the face of competitive environment through continuous response, dynamic and rapid. (Qrunfleh \& Tarafdar, 2014).

Port Authorities (PA) and Terminal Operating Companies (TOC) show a very important roles in hinterland transports by providing services to shipping line companies and shipping agent (Panayides, 2006). Many retailers and manufacturers outsource logistic activities to serve providers talented of providing a wide range of logistical \& supply chain facilities (De Langen \& Chouly, 2009). Slack and Fremont (2005) pointed out that; the global market expansion of container referred to outstanding terminal operators. They are playing an important role in the boosting of supply chain and logistics facilities. Ports need to be speedy and agile to respond to every changes in international markets in order to be responsive and competitive (Marlow \& Casaca, 2003).

Terminal operating companies (TOC) have a powerful impact on customer relationship (shipping lines, agencies and shippers). Therefore, they need to enhance their rules, regulations and position in logistics and supply chain (Peck, 2005). In some other examples, the terminal operating companies are focusing on local domination of the supply chain and logistics services. (Mason \& Lalwani, 2006) described the initiatives of (TOCs) in terms of expansion of services to provide a range of supply and logistics facilities as warehousing and other adding value facilities. Thus, expansion in these types of supply chain and logistic facilities is due to economies of scope strategies. The integrated products and services can support the terminal operating companies to differentiate itselves., (Yeo, Roe \& Dinwoodie, 2008). The services of TOCs have becoming more integrated when great facilities are offering. For example; Hutchinson Port Holdings, world's largest terminal operator, increasingly invests in additional services, for example, road transport and inland supply chain and logistics facilities. Another example is PSA Corporation (Singapore), one of the largest terminal operator, which strongly invests in logistics zones in China, (De Langen \& Chouly, 2009).

According to Wiegmans et al. (2008), Table 1 summarizes the criteria used by shipping lines to select the port. Based on these criteria, ports can develop their competitive advantage in this area. Based on these criteria and the above factors that attract shipping lines companies to use specific ports, this study tries to compare between Jabal 
Ali port and Sohar port to reflect the competitiveness of Gulf region ports. The increasing demand of world market and volume of cargo; boosts third party logistics and freight forwarding activities. The use of container ports as sea transportation is valuable due to the convenient facilities and the competitive rates of transport when compared with other transport modes. Moreover, other advantages of sea transportation (Van Thai \& Grewal, 2005). The dynamic logistics and supply chain activities need to increase the international relationships among markets nodes (Bourlakis, Melewar, Yeo, Roe \& Dinwoodie, 2011).

\begin{tabular}{|c|c|c|c|c|c|c|c|c|c|}
\hline Criteria & APL & CMACGM & cosco & Evergreen & Hanjin & Maersk & MSC & OOCL & Yang Ming \\
\hline $\begin{array}{l}\text { Availability of hinterland } \\
\text { connection }\end{array}$ & $\mathrm{X}$ & $\mathrm{x}$ & $\mathrm{x}$ & $\mathrm{x}$ & $\mathrm{x}$ & $\mathrm{x}$ & & $\mathrm{X}$ & $\mathrm{X}$ \\
\hline Size of available hinterland & $\mathrm{X}$ & $\mathrm{X}$ & $\mathrm{X}$ & $\mathrm{x}$ & & & & $\mathrm{X}$ & \\
\hline $\begin{array}{l}\text { Depth of port approaching } \\
\text { route }\end{array}$ & $\mathrm{X}$ & & & & & & & $\mathrm{x}$ & \\
\hline $\begin{array}{l}\text { Port ship time (port } \\
\text { productivity) }\end{array}$ & & $\mathrm{x}$ & $\mathrm{x}$ & & $\mathrm{X}$ & $\mathrm{x}$ & & $\mathrm{x}$ & \\
\hline $\begin{array}{l}\text { Reliability of port services } \\
\text { and labour }\end{array}$ & & $\mathrm{x}$ & & & $\mathrm{x}$ & & & $\mathrm{x}$ & \\
\hline $\begin{array}{l}\text { Port charges (reasonable } \\
\text { pricing) }\end{array}$ & $\mathrm{x}$ & $\mathrm{x}$ & $\mathrm{X}$ & $\mathrm{x}$ & $\mathrm{x}$ & $\mathrm{x}$ & $\mathrm{x}$ & $\mathrm{x}$ & \\
\hline Degree of congestion & & & X & & $\mathrm{X}$ & & & & \\
\hline
\end{tabular}

Table 1. Overview of Criteria's for Choice by Shipping Lines (Wiegmans et al., 2008: page 529)

Some authors have pointed out some factors that impact port selection (Gi-Tae et al., 2014). Their study extracted the following factors from a survey administered to thirty professionals who work closely in logistics and supply chain activities involving shippers, ship owners, logistics firms, shipping company's managers and freight organizations. They determined seven principle factors by using factor analysis, which were ports service, hinterland condition, availability, convenience; logistics cost, regional center and connectivity, which providing a framework for evaluating the structure of port competition.

The strong need for supply chain and logistics sectors leads to creation of tough competition among firms to match their services quickly to customers' needs (Tammela, Canen \& Helo, 2008). Logistics and supply chain are a vital part of global markets, because it controls whole the chain of production, allocation of goods, transportation efficiency and effectiveness, provide fuel and its cost (Tongzon, 2009). In the United States, Europe and Japan, the quick development of the logistics sector found to be faster. China now is included in this great competition, plus India which creates a position for itself in this race to be considered as a modern economic strength (Kaisar, Pathomsiri \& Haghani, 2006).

\section{Study Conceptual Framework}

The concept of port competitiveness which influences shipping lines selection of specific port is relatively recent as a research issue although there were several studies that examined the relationships between some selected factors and the port preferences from the shipping lines perspectives (Wiegmans et al., 2008; Van Thai \& Grewal, 2005; Bourlakis et al., 2011; Gi-Tae et al., 2014; Tammela et al., 2008; Tongzon, 2009; Jie et al., 2015). This concept is still difficult to understand because of its multidimensional nature. The concept must take into account a set of factors and facilities either provided by the port itself or by the country where its located. This paper will try to balance both sets of factors. Therefore; the framework is intended to show the relationship between shipping lines preferences on Sohar Port and the availability of the selected facilities (infrastructure; hinterland; connectivity and port dues) as influential factors. 


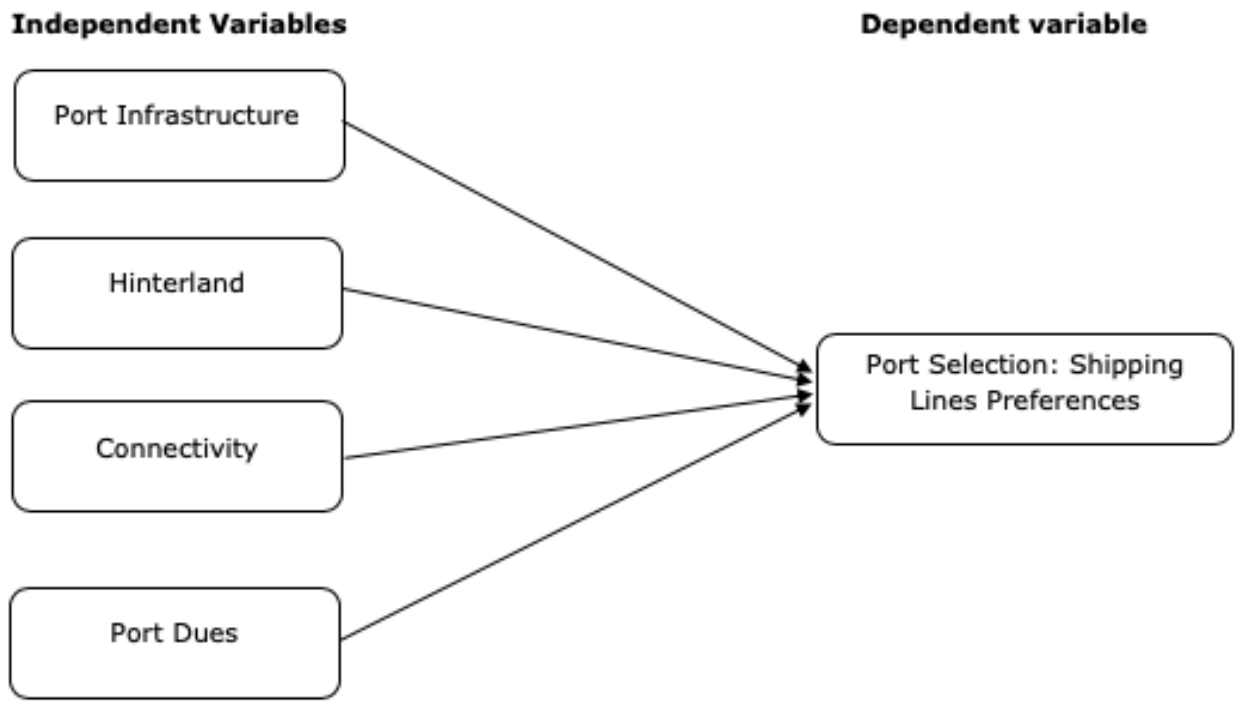

Figure 1. Conceptual Framework

\section{The Study Main Aim}

In general; the aim of this study is to explore the factors that influence port competitiveness in Gulf region from the shipping lines companies' perspective. To identify the reasons behind the shipping lines companies' preferneces to Port of Sohar in the Sultanate of Oman. Part of this is due to the strategic location of Sohar port outside of Strait of Hurmuz. The study focuses on factors that more attractive for shipping lines companies to prefer Sohar port. Moreover; the study aims to identify the integrative role of Sohar Port into logistics and supply chain.

\section{Research Objective}

Specifically; the study tries to achieve the following objectives from shipping lines perspective:

1. To study the impact of infrastructure on port selection.

2. To study the impact of hinterland transport on port selection

3. To study the impacts of connectivity operations on port selection

4. To Study the impact of port dues on port selection.

\section{Research Questions}

To investigate the factors that encourage shipping lines to select or prefer Sohar port over the others in the region, the study seeks to answer the following questions:

1. To what extent infrastructure affect the port selection?

2. To what extent hinterland affect port selection?

3. To what extent connectivity affects port selection?

4. To what extent port dues affect port selection?

\section{The Study Hypothesis}

Based on the study objectives and stated questions, the study hypothesized the following:

1. The port selection is positively affected by infrastructure availability.

2. The port selection is positively affected by hinterland.

3. The port selection is positively affected by port connectivity.

4. The port selection is positively affected by port dues. 


\section{Methodology}

The main goal of this study is to assess the factors that affect the port competitiveness in the Gulf Region. These factors encourage shipping line companies and agencies to select between regional ports. The scope of this study is to assess to what extent infrastructure, hinterland, connectivity and port dues affect the port selection from shipping lines companies and agencies' perspectives.

To collect the right data that will help in achieving the objectives of this study both quantitative and qualitative research methods were used. To collect primary qualitative data, semi-structured interviews were prepared. First, at the planning and preparation step for the interviews. emails were sent to respondents from Sohar port and free zone who have responded and actively participated later to this part of the study. Audio recording techniques were used to record and notes and transcript were taken for the purpose of the study. The list of interviewees included six executives from Sohar Port authority and one agent.

The second tool used to collect the primary quantitative data was the questionnaire. A simple questionnaire was developed covering the main constructs of the study, infrastructure, hinterland, connectivity and port dues, which related to the study objectives, questions and hypotheses. These constructs have been assessed by some selected variables to measure their impact on port selection. The construct measurement through the selected variable based on Likert scale. The general information also has been included in the questionnaire to effectively assess the impact of these factors on port selection.

\begin{tabular}{|l|l|}
\hline \multicolumn{1}{|c|}{ Global Shipper/ Local agents } & \multicolumn{1}{c|}{ Global Shipping Lines } \\
\hline Al-Fayha Shipping Agencies LLC. & APL \\
\hline Mutrah Shipping \& Trading Agency LLC & MISUI O.S.K. LINE \\
\hline Transworld Shipping Trading and Logistics Services LLC & CMA CGM \\
\hline Khimii Ramdas \& Co (Shipping Division) & UASC \\
\hline Sharaf Shipping Services \& Co L.L.C. & OOCL \\
\hline Modern Shipping Services LLC & HANJIN \\
\hline LBH Zawawi Shipping \& Logistics LLC & OCL \\
\hline Gulf Agency Company L.L.C. & CSAV \\
\hline UNIVERSAL FREIGHT SERVICES CO LLC & OSC \\
\hline MAERSK Shipping Services \& Co. & MAERSK \\
\hline Merchant Shipping Services LLC & CHINA CHIPPING \\
\hline Al Jazeera Shipping SAOC & Ships Agency \& International Logistics Co. LLC \\
\hline
\end{tabular}

Table 2. Sample List of Shipping Lines/Agents

The total number of ship agents and shipping lines operating in Sohar Port is around 47 at the time of conducting the study. The paper has targeted 30 of them as a sample. The response rate was found to be 77 percent. The responses were received from (23) shipping lines companies and agents operating in Sohar Port. These responses were from global shipping lines and local agents of global shipping lines. Table 2, shows a sample of the main shipping lines operating in Sohar Port. After data collection, statistical analysis has been performed to measure the descriptive statistics (mean, Mode, Median and Standard deviation). For teswting hypotheses, t-test, one-sample test and ANOVA were used. Statistical Package of Social Sciences (SPSS) was used to conduct these tests.

The reliability test was conducted for each set of variables used to measure the defined construts. The result shows that the variables used to measure the four construct are reliable as the minimum number of items for each construct is four (port dues) and the máximum nuber of items is 7 (infrastructure). The least Cronbach's Alpha was found fto be for connectivity (56 percent) and the highest alph was found to be for infrastructure ( 75 percent) 


\section{Results}

This section will show the main result achieved by using both interviews and questionnaire. The first part will reflect on the general information about the respondents. The second part will show the detailed statistics about the study constructs and how they influence the shipping lines preferences and port selection. The third part express the hypotheses testing and finally the fourth part shows the qualitative data analysis.

\section{Respondents' Profile}

Table 3 shows the demographic profile of the respondents, who participated in the survey. It is evident that majority of shipping lines and agents are operating feeder only (56.5 percent) while those who are both operating feeder and deep sea representing 21.7 percent. The frequency of vessels terminals once a week, 56.5 percent and twice a week represented by 43.5 percent. They have been requested to rank the importance of infrastructure, hinterland, connectivity and dues in their selection of Sohar port and their responses were as follows:

With respect to infrastructure, 91.3 said the it is very important. Infrastructure for ports includes warehousing availability, availability of assembly facilities/testing/distribution, proximity of manufacturing facilities, size of cranes/quays/yard and other terminal infrastructure, could chain infrastructures. Around 30.4 percent of respondents said that hinterland is on average important and above, while 34.8 percent said connectivity is on average important and above. Port connectivity includes the geographic location, availability of connecting services (feeder and short sea), reliability and frequency of feeder network, in-land connectivity road/rail, and proximity and connection to airport.

Around 47.8 percent said that port dues are on average important and above for them in taking the decision to select Sohar port. Port dues includes cost of trucking and rail, overall supply chain costs, customer fees, port and terminal fees, and taxes. Operational efficiency was ranked on the top of selection criteria which includes port productivity (crane movements), operating hours, reliability of port and flexibility in case of delay, container equipment availability, container dwell time. In addition; customer procedures and service level also considered as criteria for port selection which includes, speed of customers, clarity of customs procedures, availability of port free zone, services and education level of port related staff, offering of e-services (cargo tracking), availability of e-booking services and additional vessels services.

Cost and Connectivity were ranked as the most important port selection criteria taking into consideration the infrastructure as an out layer. Therefore; the limited land for future expansion considered to be another threat facing Sohar Port and free zone. Looking to the future more expansion will be needed. But due to the surrounded residential areas on both sides of Sohar Port; the expansion will be difficult. The expansion of the port will be very challenging and expensive.

The following section will give more details and statistics on infrastructure, hinterland, connectivity and dues. Table 4 shows that the majority of shipping lines and agents agreed that there were low frequencies of cargo loss and damages. In addition; the majority of them said that the availability of warehousing at Sohar port is appropriate. These two factors are considered important for selecting Sohar port. Storage facilities and harbor depth have the lower rank in appropriateness. This lead to the need for more focus on these areas to improve Sohar Port competitiveness. Shipping lines and agents agreed that Sohar port is having good equipment and cranes which help it in handling large volume of cargo. In general, the aggregate statistics on infrastructure are good and promising in improving Sohar port competitiveness. The standard deviations show that there is no variability among their responses.

Table 5 showed that the majority of shipping lines and agents agreed that switching to other port is easy and convenient. The respondents appreciated the location and easy and convenient searching for container at Sohar port. The hinterland connection from Sohar port also found to be appropriate for most of the shipping lines. It is clear from the statistics that Sohar port have a problem with the provision of value added services. In general, the aggregate statistics of the shipping lines companies and agents' perspectives on hinterland are positive and imply that Sohar port needs to focus more on value added services provision and capitalize on other advantages specially the strategic location. 


\begin{tabular}{|c|c|c|}
\hline Item & Description & Frequency \\
\hline \multirow{3}{*}{ Shipping line the company is Operating } & Feeder & 56.5 \\
\hline & Deep Sea & 21.7 \\
\hline & Both & 21.7 \\
\hline \multirow{2}{*}{ Frequency of the Vessels at terminals } & Once A week & 56.5 \\
\hline & Twice A week & 43.5 \\
\hline \multirow{2}{*}{$\begin{array}{l}\text { To what extent infrastructure important } \\
\text { for you }\end{array}$} & Average Important & 8.7 \\
\hline & Very Important & 91.3 \\
\hline \multirow{4}{*}{$\begin{array}{l}\text { To what extent Hinterland is important } \\
\text { for you }\end{array}$} & Not Important & 34.8 \\
\hline & less Important & 34.8 \\
\hline & Average Important & 26.1 \\
\hline & Very Important & 4.3 \\
\hline \multirow{4}{*}{$\begin{array}{l}\text { To what extent Connectivity is important } \\
\text { for you }\end{array}$} & Not Important & 21.7 \\
\hline & less Important & 43.5 \\
\hline & Average Important & 26.1 \\
\hline & Very Important & 8.7 \\
\hline \multirow{4}{*}{$\begin{array}{l}\text { To what extent Port Dues is important } \\
\text { for you }\end{array}$} & Not Important & 26.1 \\
\hline & less Important & 26.1 \\
\hline & Average Important & 43.5 \\
\hline & Very Important & 4.3 \\
\hline
\end{tabular}

Table 3. Respondents' Profile

\begin{tabular}{|c|c|c|c|c|c|}
\hline Statement & $\mathbf{N}$ & Mean & Median & Mode & $\sigma$ \\
\hline There is an appropriate infrastructure in Sohar Port & 23 & 3.17 & 3.00 & 2.00 & 1.154 \\
\hline There are low frequencies of cargo loss and damage & 23 & 3.57 & 4.00 & 4.00 & 0.896 \\
\hline Equipment and Gantry cranes are available in this port & 23 & 3.22 & 3.00 & 4.00 & 1.085 \\
\hline Storage facilities are available for containers and goods & 23 & 3.22 & 3.00 & 2.00 & 1.204 \\
\hline The harbor depth at this port is sufficient & 23 & 3.17 & 3.00 & 3.00 & 0.937 \\
\hline This port have the ability to handle large volume of cargo & 23 & 3.22 & 3.00 & 3.00 & 1.085 \\
\hline The warehousing availability at this port is appropriate & 23 & 3.43 & 4.00 & 4.00 & 0.896 \\
\hline Aggregate Statistics for Infrastructure & 23 & 3.29 & 3.43 & 3.57 & 0.535 \\
\hline
\end{tabular}

Table 4. Shipping Lines and Agents Perspectives on Sohar Port Infrastructure

\begin{tabular}{|c|c|c|c|c|c|}
\hline Statement & $\mathbf{N}$ & Mean & Median & Mode & $\sigma$ \\
\hline The hinterland connections from this port are appropriate & 23 & 3.35 & 3.00 & 3.00 & 1.071 \\
\hline Searching the status of the container at this port is convenient & 23 & 3.30 & 3.00 & 3.00 & 0.926 \\
\hline Value added services at this port are provided & 23 & 3.09 & 3.00 & 2.00 & 1.083 \\
\hline The location of the port is considered when selecting terminal & 23 & 3.57 & 3.00 & 3.00 & 0.788 \\
\hline Breaking relationship with port and switch to another is easy & 23 & 3.65 & 4.00 & 4.00 & 1.071 \\
\hline Aggregate Statistics for Hinterland & 23 & 3.39 & 3.40 & 3.20 & 0.524 \\
\hline
\end{tabular}

Table 5. Shipping Lines and Agents Perspectives on Sohar Port Hinterland 
Table 6 indicated that the majority of shipping lines companies and agents confirmed that personal relationships and contacts are very important in selecting Sohar port. They also agreed that the total stay of vessels at berth is short while total stay at anchorage is long. On average they confirm that Sohar port attracts main shipping lines while at the same time they are not sure that it will be a distribution hub for GCC and Indian subcontinent. The statistics also showed that the shipping lines companies and agents agreed that the connectivity is good at Sohar port.

Table 7 showed the statistics related to Sohar port dues. It is clear that the shipping lines companies and agents are not satisfied with the dues and prices of services compared to other regional ports. They agreed that the equipment, tools and services provided by the port are appropriate. Some of them agreed that they have invested in the equipment and services to make it quick and convenient for them. This was reflected on the average time of container loading and discharge, which found to be convenient as they see it.

\begin{tabular}{|c|c|c|c|c|c|}
\hline Statement & $\mathbf{N}$ & Mean & Median & Mode & $\sigma$ \\
\hline The Connectivity from this port is good & 23 & 3.57 & 3.00 & 3.00 & 1.080 \\
\hline The total stay of Vessel at anchorage areas is short & 23 & 3.13 & 3.00 & 2.00 & 1.140 \\
\hline The total stay of Vessel at berth is short & 23 & 3.57 & 4.00 & 3.00 & 1.037 \\
\hline Personal contract and relationships are important when selecting the port & 23 & 3.39 & 3.00 & 4.00 & 0.988 \\
\hline This port attracts main shipping lines & 23 & 3.04 & 3.00 & 3.00 & 0.878 \\
\hline This port is a distribution hub for the GCC and Indian subcontinental & 23 & 3.35 & 3.00 & 2.00 & 1.112 \\
\hline Aggregate Statistics for Connectivity & 23 & 3.34 & 3.33 & 3.00 & 0.581 \\
\hline
\end{tabular}

Table 6. Shipping Lines and Agents Perspectives on Sohar Port Connectivity

\begin{tabular}{|c|c|c|c|c|c|}
\hline Statement & $\mathbf{N}$ & Mean & Median & Mode & $\sigma$ \\
\hline The Port dues and prices are fair compared to other ports & 23 & 3.17 & 3.00 & 2.00 & 0.984 \\
\hline The container loading/discharging rate per hour at this port is convenient & 23 & 3.17 & 3.00 & 3.00 & 0.984 \\
\hline The equipment, tools, and services provided are appropriate & 23 & 3.48 & 4.00 & 4.00 & 1.082 \\
\hline $\begin{array}{l}\text { Our company has invested in the equipment, tools and services of this } \\
\text { terminal to make services quick and convenient for us }\end{array}$ & 23 & 3.17 & 3.00 & 3.00 & 1.114 \\
\hline Aggregate Statistics for Port Dues & 23 & 3.25 & 3.25 & 3.25 & 0.612 \\
\hline
\end{tabular}

Table 7. Shipping Lines and Agents Perspectives on Sohar Port Dues

\section{Test of Hypotheses}

The stated hypotheses postulate that the port selection is positively affected by infrastructure availability, hinterland, connectivity and port dues. Table 8 showed the one-sample test where the statistics of these four constructs were shown. It is clear that the significant level of these features are less than the significant level of 0.05 , except for port dues. This reflects that the first three features, namely (infrastructure, hinterland and connectivity) have a positive impact on port selection from shipping lines and agents' perspectives. While the port dues found to be insignificant and the level is more than 0.05 , which means that the dues have a negative effect on port selection. Therefore; shipping lines and agents are preferring Sohar port because of the first three features when they compare it with the other regional ports.

Sohar port therefore; needs to focus more on the services provision and dues. The port while providing high level facilities and services, it needs to consider the prices of these services to attract more shipping lines and agents to operate through the port. To be more competitive compared to the regional ports, Sohar port also need to be connected with complementary infrastructure and services as roads, railways, and airports to complete the supply chain series and to be a distribution hub for the pother GCC as it targets. 
Table 9 showed the analysis of variance (ANOVA), for types of shipping lines companies operating in Sohar port. Using ANOVA, the four Sohar port features or factors which expected to affect the port selection by the shipping lines companies and agents were further evaluated to assess the level of their significance on port selection based on whether the company operating feeder or deep sea. The analysis revealed that only one factor is acceptable with significance level less than (0.05), which is hinterland. The F values indicates significance differences among groups, and the higher the F values, the more likely that the null hypotheses are rejected. This reflects that there are differences between types of shipping lines companies and agents with respect to hinterland and there are no differences with respect to infrastructure, connectivity and dues.

\begin{tabular}{|c|c|c|c|c|c|c|}
\hline \multirow[b]{3}{*}{ Constructs } & \multicolumn{6}{|c|}{ Test Value $=3$} \\
\hline & \multirow[b]{2}{*}{$\mathrm{t}$} & \multirow[b]{2}{*}{ df } & \multirow[b]{2}{*}{ Sig. (2-tailed) } & \multirow{2}{*}{$\begin{array}{c}\text { Mean } \\
\text { Difference }\end{array}$} & \multicolumn{2}{|c|}{$\begin{array}{l}95 \% \text { Confidence Interval } \\
\text { of the Difference }\end{array}$} \\
\hline & & & & & Lower & Upper \\
\hline Infrastructure & 2.563 & 22 & .018 & .28571 & .0546 & .5169 \\
\hline Hinterland & 3.582 & 22 & .002 & .39130 & .1648 & .6179 \\
\hline Connectivity & 2.813 & 22 & .010 & .34058 & .0895 & .5916 \\
\hline Dues & 1.958 & 22 & .063 & .25000 & -.0148 & .5148 \\
\hline
\end{tabular}

Table 8. One-Sample Test

\begin{tabular}{|c|c|c|c|c|c|c|}
\hline \multicolumn{2}{|c|}{ Constructs } & \multirow{2}{*}{$\begin{array}{r}\text { Sum of Squares } \\
.311\end{array}$} & \multirow{2}{*}{ df 2} & \multirow{2}{*}{$\begin{array}{r}\text { Mean Square } \\
.155\end{array}$} & \multirow{2}{*}{$\begin{array}{l}\text { F } \\
.520\end{array}$} & \multirow{2}{*}{$\begin{array}{l}\text { Sig. } \\
.602\end{array}$} \\
\hline \multirow{3}{*}{ Ifrastructure } & Between Groups & & & & & \\
\hline & Within Groups & 5.975 & 20 & .299 & & \\
\hline & Total & 6.286 & 22 & & & \\
\hline \multirow{3}{*}{ Hinterland } & Between Groups & 1.786 & 2 & .893 & 4.200 & .030 \\
\hline & Within Groups & 4.252 & 20 & .213 & & \\
\hline & Total & 6.038 & 22 & & & \\
\hline \multirow{3}{*}{ Connectivity } & Between Groups & .548 & 2 & .274 & .798 & .464 \\
\hline & Within Groups & 6.868 & 20 & .343 & & \\
\hline & Total & 7.415 & 22 & & & \\
\hline \multirow{3}{*}{ Dues } & Between Groups & .698 & 2 & .349 & .924 & .413 \\
\hline & Within Groups & 7.552 & 20 & .378 & & \\
\hline & Total & 8.250 & 22 & & & \\
\hline
\end{tabular}

Table 9. Analysis of Variance (ANOVA) for Shipping Lines Companies (Feeder \& Deep Sea)

\section{The Analysis of Interviews}

The majority of the interviewees agreed that Sohar port and free zone is characterized by a natural depth of port which located on a deep sea and does not require doing a lot of judging and this is considered a competitive advantage to Sohar port. On the other hand, they argued that the land lord model used in Sohar port means that there are independent terminals and the operators are known which creates a good reputation. The companies in Sohar port have proven to be a very successful companies, because they have achieved a lot of milestones around the world and they are very well known because of this. The landlord model for other interviewees, is suitable for Sohar port and free zone because, Hutchison, Oil tanking Odfjell and C Stenweg are big operators and have their loyal customers and when they bring them to Sohar, using their networks, Sohar Port and Free Zone will be known and famous. Consequently; the chance of the local private sector will get more chances and benefits. Landlord 
model for others, has its own weaknesses. For example; the role of the port authority mixed with the role of the terminals. Sometimes there is a gap or overlap between the authorities in resolving issues pricing services.

Sohar port found to be providing a range of services which involve pilotage, tugging and bunkering, linesman, port dues, etc. These services are available $24 / 7$ with a zero-waiting time. Benchmarking with other regional ports will be helpful to upgrade Sohar port services. For example; Port of Jabal Ali in Dubai, provides fresh water, cleaning services and marine services. It was also found that there is schedule of vessels, but sometime ships come in without notice and it is difficult to fit in these unscheduled vessels along with scheduled ships which may cause delays. For these busy time Port should give free waiting time for five days in the anchorage area.

The majority of interviewees argued that Sohar port has increased its market share in the region due to its competitive advantages which mainly based on its strategic location. There may be a competition in certain products or general cargo for example, pipe production and discharge and all types of cars being dispatch by Sohar Port and free zone, because, it is an unsophisticated port and there is no need to make big volumes to attracts vessels to come to the port. The port needs to enhance its competitive position as its main objective is to establish new business and market share in today's dynamic supply chain needs.

From the interviews it is clear that shipping lines companies focus on hinterland conditions of Sohar port. The availability of logistics centers, transportation infrastructure and the existences of rail and connectivity with nearby markets and other ports are also important. In case they are looking for a transshipment hub, shipping line do not care about hinterland conditions. The terminal itself should have enough storage capacity and a good feeder's service plus easy access deliver goods to other ports or destinations. This prove that door to door services is very important criteria for port selection.

Independent terminals and strategic joint venture with Rotterdam port are a unique advantage of Sohar port because it is the largest port in Europe and one of the top ports in the world. Because Sohar Port and free zone are parts of this association, it is very convenient to increase market share. They are not just a normal port but they have big industries for example, Sohar refinery, Vale, Jindal, Methanol and Odell. It became clear that Sohar Port Authority plays an important role in improving port operation by making sure that the infrastructure is there whichever through themselves or through government. They provide jetties, quay walls, main roads, berths and marine related infrastructure. Moreover, they give concessions to the right people and evaluate their terminals for capability of the operators and their technical know-how. Port authority has strong impact on port operations and should be more dynamic and sophisticated to cope with rising needs.

There is a need for the cargo handlers to be experienced. As interviewees repeatedly mentioned that the port Authority closely monitors how operators are doing their business. Sometimes operators will charge higher rate for their services. Moreover, the customers can be misled by being told that these higher prices are because Sohar port and free zone is very expensive and customers must pay for the additional cost of feeders. Before the agreement is signed with terminal operators Sohar Port Authority ensures the main key term with operator. They should remain competitive and take into account the strong competition with UAE port because they are the main competitors. Port Authority provides enough space for investors and businesses and keep in mind the future expansion plans because the business is moving very fast.

The government is one of the stakeholders represented by Customs, Immigration, The Ministry of Health and Agriculture in addition, to the Ministry of Transportation which provide the hinterland infrastructure for Sohar port. If there is any delay in infrastructure development that means a delay in port progress. For instance, if there is damage in breakwaters, the government should do maintenance and if the clients delay their process, the flow of cargo will be delayed. So the government is a very important companion in these activities and have a direct role. It is highly important to integrate and coordinate the supply chain process between partners and stakeholders including the government. They can either make the process move very smoothly or they will complicate the daily operation of the port. Integration between government and other stakeholder is the key element of Sohar port success.

Rules and regulations were also discussed during interviews. The local rules and regulations in Oman which required to be followed by ships and ports are in line with the international practices. For some interviewees the 
rules and regulations in Oman sometime slow down their operations as several approvals have to be obtained which can take more than expected. Rules, legislation and regulations have long term impacts on port operations.

\section{Conclusion and Future Research}

The present study concluded that there are positive impacts of infrastructure, hinterland, connectivity and port dues on shipping lines companies and agents' preferences about Sohar port. Availability of infrastructures found to be attracting shipping lines companies and agents to use Sohar port. In terms of port connectivity, there are excellent roads with travel times of only two hours to Dubai, Abu Dhabi, Alain and Muscat. The Government is almost finalizing Al Batinah Express Way and Costal Road which will link more that $80 \%$ of populated regions in Oman to help the movement of shipping Cargos. In term of shipping connectivity, the port has a lot of feeder services that take cargo from the port to other regional ports in Indian and Pakistan as they are main markets for transshipment.

The first phase of the free zone is almost fully leased out, three years ahead of schedule, and some 26 companies are already reaping the benefits of unrivalled access to land, low cost and skilled workforce. Free Zone creates a lot of job volume to Sohar port, because most of the industries are importing and exporting through the port. As stated by one interviewees "Trade in Oman, both import and export, is continually growing. Food, construction materials and machinery are our biggest imports while oil related products remain as our biggest export." Sohar Port and free zone is connected to well establish network roads that enable it to facilitate shipment of cargo by using multimodal transport system. It is well connected by roads to Muscat and UAE, because Sohar port is in a central location of these growing markets. Moreover, the new airport in Sohar which is located nearby the logistic center and near the port, will boost the role of the port and will increase the volume of cargo going through it.

Port of Sohar is equipped with one of the deepest jetties in the world that can berth the largest carriers. There are transshipment services in Sohar port and Free Zone, but found to be not sufficient. In term of size, the biggest vessel Sohar Port received is Vale max with 400,000 dead weight which is part of fleet of very large are carriers in the world. These vessels require a huge depth of 25 meters. Moreover, to dedicated jetty is required for receiving those type of vessels alongside the sea which is available in Sohar Port. Sohar Port and free zone are much closer to the international markets. It is strategically located outside the Strait of Hormuz which cause the port to be in the middle of the world and close to the most populated nations of the GCC countries, Iran and Indian subcontinent. This gives the opportunities to Sohar port to reach, access and serve these markets.

Sohar port follows a landlord model, which encourages repeated terminal operation companies to start their businesses. Availability of world class terminals and reputable names in the world make the shipping lines and agents more comfortable to do their businesses. Companies like Hutchison, C. Stenweg and Oil tanking Odfjell are very successful and well- known companies, because they have achieved a lot of milestones around the world. As they are operating in Sohar port, they encourage other shipping lines companies from their networks to do business in Sohar Port.

Port of Sohar is a fast growing port and it has a strategic location being outside of the Strait of Hormuz. It needs more expansion especially in the infrastructure and hinterland, such as increasing numbers of berths, reducing the vessel waiting time and reviewing the rate of port services. It should give more attention to infrastructure, hinterland and port dues to attract more investors, shipping lines and big mother vessels in order to compete with other nearby ports as the Port of Jabil Ali. Sohar port has an opportunity to continue competing regionally and internationally, however structured strategic approach must be developed, implemented and continually reviewed and assessed. The strategy must include continues benchmarking, branding, marketing and communication aspects. The port authority needs to work very closely with government to facilitate doing business and encourage foreign investors and the local private sector.

As this study has focused on a limited number of shipping lines companies and agents operating in Sohar port, and considered only four factors expected to have influence on port selection, generalization will be not possible. It will be useful for future researchers to include more companies operating in the region and to consider global shipping lines and agents which have not contributed to this study. a comparative study will also be beneficial to reflect the 
differences among regional ports. There an opportunity for researches in a wide range by involving more regional ports to investigates more factors that encourage shipping lines companies and agents to use Arabian Gulf ports including Sohar port.

\section{Declaration of Conflicting Interests}

The authors declared no potential conflicts of interest with respect to the research, authorship, and/or publication of this article.

\section{Funding}

The authors received no financial support for the research, authorship, and/or publication of this article.

\section{References}

Bourlakis, M., Melewar, T., Yeo, G.T., Roe, M., \& Dinwoodie, J. (2011). Measuring the competitiveness of container ports: logisticians' perspectives. European Journal of Marketing, 45, 455-470.

https://doi.org/10.1108/03090561111107276

Chen et al. (2006). A fuzzy approach for supplier evaluation and selection in supply chain management. Int. J.

Production Economics, 102, 289-301. https://doi.org/10.1016/j.ijpe.2005.03.009

Coltman, T., \& Devinney, T.M. (2013). Modeling the operational capabilities for customized and commoditized services. Journal of Operations Management, 31, 555-566. https:// doi.org/10.1016/j.jom.2013.09.002

De Langen, P.W., \& Chouly A. (2004). Hinterland Access Regimes in Seaports- European Journal of Transport and Infrastructure Research (EJTIR), 4(4), 361-380.

De Langen, P., \& Chouly, A. (2009). Strategies of terminal operating companies in changing environments. International Journal of Logistics: Research and Applications, 12, 423-434. https://doi.org/10.1080/13675560902775725

Ellram, L.M., Tate, W.L., \& Feitzinger, E.G. (2013). Factor-Market Rivalry and Competition for Supply Chain Resources. Journal of Supply Chain Management, 49, 29-46. https://doi.org/10.1111/jscm.12001

Gi-Tae et al. (2014). Modelling port choice in an uncertain environment. Journal of Maritime Policy \& Management, 41(3), 251-267. https://doi.org/10.1080/03088839.2013.839515

Gunasekaran, A., \& Sarkis, J. (2008). Research and applications in e-commerce and third-party logistics management. International Journal of Production Economics, 113, 123-126. https://doi.org/10.1016/j.ijpe.2007.07.002

Jie, Y., Subramanian, N., Ning, K., \& Edwards, D. (2015). Product delivery service provider selection and customer satisfaction in the era of internet of things: A Chinese e-retailers' perspective. International Journal of Production Economics, 159, 104-116. https://doi.org/10.1016/j.ijpe.2014.09.031

Kaisar, E. I., Pathomsiri, S., \& Haghani, A. (2006). Efficiency measurement of US ports using data envelopment analysis.

Lammers, E. (2013). Sohar so good [Online]. Available at: http://www.worldbunkering.com/news/spring-2013/1147-soharso-good.html (Accessed: May 2019).

Marlow, P.B., \& Casaca, A.C.P. (2003). Measuring lean ports performance. International Journal of Transport Management, 1, 189-202. https://doi.org/10.1016/j.ijtm.2003.12.002

Mason, R., \& Lalwani, C. (2006). Transport integration tools for supply chain management. International Journal of Logistics: Research and Applications, 9, 57-74. https://doi.org/10.1080/13675560500534599

Notteboom, T.E., \& Rodrigue, J.P. (2005). Port regionalization: towards a new phase in port development. Maritime Policy \& Management, 32, 297-313. https://doi.org/10.1080/03088830500139885

Pacific Tycoon (2014). Trade Winds, available at: https://pacifictycoon.wordpress.com/tag/general-cargo/ (Accessed: June 2019). 
Panayides, P.M. (2006). Maritime logistics and global supply chains: towards a research agenda. Maritime Economics \& Logistics, 8, 3-18. https://doi.org/10.1057/palgrave.mel.9100147

Peck, H. (2005). Drivers of supply chain vulnerability: an integrated framework. International journal of physical distribution \& logistics management, 35, 210-232. https://doi.org/10.1108/09600030510599904

Qrunfleh, S., \& Tarafdar, M. (2014). Supply chain information systems strategy: Impacts on supply chain performance and firm performance. International Journal of Production Economics, 147, 340-350.

https://doi.org/10.1016/j.ijpe.2012.09.018

Ramanathan, R. (2010). The moderating roles of risk and efficiency on the relationship between logistics performance and customer loyalty in e-commerce. Transportation Research Part E: Logistics and Transportation Review, 46, 950-962. https://doi.org/10.1016/j.tre.2010.02.002

Sahay, B., Gupta, J.N., \& Mohan, R. (2006). Managing supply chains for competitiveness: the Indian scenario. Supply Chain Management: An International Journal, 11, 15-24. https://doi.org/10.1108/13598540610642439

Slack, B., \& Fremont, A. (2005). Transformation of port terminal operators: From the local to the global. Transport Reviews, 25(1), 117-130. https://doi.org/10.1080/0144164042000206051

Steven, A.B., \& Corsi, T.M. (2012). Choosing a port: An analysis of containerized imports into the US. Transportation Research Part E: Logistics and Transportation Review, 48, 881-895. https://doi.org/10.1016/j.tre.2012.02.003

Tammela, I., Canen, A.G., \& Helo, P. (2008). Time-based competition and multiculturalism: A comparative approach to the Brazilian, Danish and Finnish furniture industries. Management Decision, 46, 349-364. https://doi.org/10.1108/00251740810863834

Tongzon, J.L. (2009). Port choice and freight forwarders. Transportation Research Part E: Logistics and Transportation Review, 45, 186-195. https://doi.org/10.1016/j.tre.2008.02.004

Van Thai, V. \& Grewal, D. (2005). Selecting the location of distribution centre in logistics operations: A conceptual framework and case study. Asia Pacific Journal of Marketing and Logistics, 17, 3-24. https://doi.org/10.1108/13555850510672359

Wiegmans et al. (2008). Port and terminal selection by deep-sea container operators. Journal of Maritime Policy \& Management, 35(6), 517-534. https://doi.org/10.1080/03088830802469329

Yeo, G.T., Roe, M., \& Dinwoodie, J. (2008). Evaluating the competitiveness of container ports in Korea and China. Transportation Research Part A: Policy and Practice, 42, 910-921. https://doi.org/10.1016/j.tra.2008.01.014

Journal of Industrial Engineering and Management, 2019 (www.jiem.org)

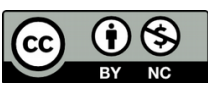

Article's contents are provided on an Attribution-Non Commercial 4.0 Creative commons International License. Readers are allowed to copy, distribute and communicate article's contents, provided the author's and Journal of Industrial Engineering and Management's names are included. It must not be used for commercial purposes. To see the complete license contents, please visit https://creativecommons.org/licenses/by-nc/4.0/. 